\title{
Ethanol extract of Cymbopogon winterianus on mortality and number of eggs of Tetranychus urticae
}

\author{
Extrato etanólico de Cymbopogon winterianus na mortalidade e no número de ovos de \\ Tetranychus urticae
}

\author{
Victor Bernardo Vicentini ${ }^{\mathrm{I}}$ Dirceu Pratissoli $^{\mathrm{I}^{*}}$ Vagner Tebaldi de Queiroz $^{\mathrm{II}}$ Adilson Vidal Costa $^{\mathrm{II}}$ \\ Patrícia Fontes Pinheiro II Fernando Domingo ZingerI Vando Miossi RondelliII
}

\begin{abstract}
Plant extracts have been studied as a promising source of natural insecticides. This study assessed the effect of the ethanol extract of Cymbopogon winterianus Jowitt (citronella grass) in comparison with an insecticide containing azadirachtin (ICA) on mortality and number of eggs of Tetranychus urticae Koch (Acari: Tetranychidae) in laboratory conditions. For the tests, the mites were sprayed with the aid of a Potter spray tower. To assess the mortality of females, $L C_{50}$ value for extract of citronella grass and ICA was, respectively, 2.63 and $2.83 \%$. With respect to the number of eggs, the greatest reduction was observed at a concentration of $5 \%$ for the evaluation period of $120 \mathrm{~h}$, both for the extract of citronella grass (86\%) and for ICA (81\%). These results suggest the potential of the ethanol extract of citronella grass to control of T. urticae. However, experiments, under field conditions, involving other populations of T. urticae should be performed to verify the efficacy of this extract as an alternative to be used in pest management programs.
\end{abstract}

Key words: two-spotted spider mite, alternative control, neem, plant extracts.

\section{RESUMO}

Extratos vegetais têm sido estudados como uma fonte promissora de inseticidas naturais. Neste trabalho, foi avaliado o efeito do extrato etanólico de Cymbopogon winterianus Jowitt (capim-citronela) em comparação com um inseticida contendo azadiractina (ICA) sobre a mortalidade e o número de ovos de Tetranychus urticae Koch (Acari: Tetranychidae), em condições de laboratório. Para a realização dos ensaios, os ácaros foram pulverizados com o auxílio da torre de Potter. Para o teste de avaliação da mortalidade de fêmeas, a $C L_{50}$, para o extrato de capim-citronela e ICA, foi, respectivamente, 2,63 e 2,83\%. Em relação ao número de ovos, a maior redução foi observada na concentração de 5\% no intervalo de avaliação de 120h, tanto para o extrato de capim-citronela (86\%) quanto para o ICA (81\%). Estes resultados sugerem que o extrato etanólico de capimcitronela apresenta potencial para ser utilizado no controle de $\boldsymbol{T}$. urticae. Entretanto, ainda devem ser realizados experimentos em condições de campo, envolvendo outras populações de T. urticae, para averiguar a eficácia deste extrato como alternativa a ser utilizada em programas de manejo da praga.

Palavras-chave: ácaro-rajado, controle alternativo, nim, extratos vegetais.

\section{INTRODUCTION}

The two-spotted spider mite, Tetranychus urticae Koch (1836) (Acari: Tetranychidae), is one of the most economically important species in the world due to its cosmopolitan occurrence and abundance in many cropping systems, including fruits, vegetables, oilseed, ornamental and medicinal plants (GALLO et al., 2002; FADINI et al., 2004; HAN et al., 2011). Infestation at production of strawberry (Fragaria $\mathrm{x}$ ananassa Duch) seedlings may cause a delay in plant development, weakening and reducing the emission of stolons, and consequently reducing the number of seedlings produced (FLECHTMANN, 1979; CHIAVEGATO \& MISCHAN, 1981).

'Laboratório de Entomologia do Núcleo de Desenvolvimento Científico e Tecnológico em Manejo Fitossanitário de Pragas e Doenças (NUDEMAFI), Departamento de Produção Vegetal, Centro de Ciências Agrárias (CCA), Universidade Federal do Espírito Santo (UFES), Alto Universitário, s/n, CP 16, 29500-000, Alegre, ES, Brasil. E-mail: dirceu.pratissoli@ufes.br."Corresponding author.

"Laboratório de Fitoquímica e Síntese de Novos Compostos, Departamento de Química e Física, CCA, UFES, Alegre, ES, Brasil.

IIILaboratório de Entomologia, Departamento de Agronomia, Universidade Federal Rural de Pernambuco (UFRPE), Recife, PE, Brasil. 
Control of the mite may be accomplished through the application of synthetic acaricides (SATO et al., 2004). However, the resistance of this pest to such products has stimulated the search for new control methods, which include the use of plant species with insecticidal and acaricidal properties. In recent years, different studies have been reported the potential of essential oils and plant extracts for control of mites (BERNARDI et al., 2012; ATTIA et al., 2013).

Cymbopogon is a plant genus of the Poaceae family widely spread in mountains, plains and arid zones of almost the entire Brazilian territory (SCHWIRKOWSKI, 2009). Belonging to this genus, C. witerianus Jowitt e $\boldsymbol{C}$. nardus (L.) Rendle are perennial and rhizome forming plants known as citronella grass (JAYASINHA, 1999). In Brazil, commercial cultivation for citronella grass has gained prominence due to its external trade and huge industrial applications (BIZZO et al., 2009).

Insecticidal and larvicidal activities of extracts obtained from leaves of plants of the genus Cymbopogon have been reported (ADAKOLE \& ADEYEMI, 2012; THEIN et al., 2013). THEIN et al. (2013) reported that extract of citronella grass leaves provided the highest repellency against Sitophilus spp. and similar level of repellency to langkauas (Alpinia galanga (L.) Willd.) against Callosobruchus chinensis.

Considering the occurrence of citronella grass plants and strawberry crops economic relevance in Brazil, the potential of the ethanol extract obtained from $\boldsymbol{C}$. winterianus leaves was evaluated in laboratory conditions on the mortality and number of eggs of T. urticae in order to contribute to the development of alternative methods for controling strawberry crop pests.

\section{MATERIAL AND METHODS}

\section{Rearing of Tetranychus urticae}

Tetranychus urticae adults were collected in January at the Serrano Center of the Capixaba Institute of Research, Technical Assistance and Rural Extension (INCAPER, ES, Brazil). The mites were kept on detached leaves at plastic Petri dishes at $25 \pm 1^{\circ} \mathrm{C}, 70 \pm 10 \% \mathrm{RH}$ and photophase of 12 hours. Leaves were renewed at 5-7 days intervals.

\section{Plant extract}

Leaves of $\boldsymbol{C}$. winterianus were collected from the garden of the Center for Scientific and Technological Development in Phytosanitary Management of Pests and Diseases (NUDEMAFI,
Alegre, ES, Brazil) and kept at $40^{\circ} \mathrm{C}$ for 72 hours in a forced air oven (S480AD, Biopar, Porto Alegre, RS, Brazil). Later, the leaves were ground in a knife mill (MA-340, Marconi, Piracicaba, SP, Brazil) with $0.8 \mathrm{~mm}$ sieve and stored in airtight plastic containers. A paper cartridge was filled with citronella grass powder $(5 \mathrm{~g})$ and then transferred to an oil and grease extractor (MA-491, Marconi, Piracicaba, SP, Brazil). Absolute ethanol (99.8\% ACS) was added to extraction chamber until complete cartridge immersion. The extraction was performed overnight at $110^{\circ} \mathrm{C}$. After this, ethanol was completely removed from the extract by heating in a forced air oven for 48 hours at $40^{\circ} \mathrm{C}$. The commercial insecticide used was Azamax $^{\circledR}$ (DVA AGRO DO BRASIL, Campinas, SP, Brazil) wich contains azadirachtin at a concentration of $1.2 \%(\mathrm{w} / \mathrm{v})$ and was used as positive control. Azamax $^{\circledR}$ will be referred throughout the text as insecticide containing azadirachtin (ICA).

The ethanol extract of citronella grass and ICA were used for preparation of formulations at 1,2, 3,4 and $5 \%(\mathrm{v} / \mathrm{v})$. Distilled water was used as solvent and control (concentration $0 \%$ ) for the ethanol extract of citronella grass and ICA.

\section{Experimental procedure}

Strawberry leaves of the Camarosa variety were washed with distilled water, immersed in a sodium hypochlorite solution ( $1 \%(\mathrm{v} / \mathrm{v}))$ for 1 minute, and again washed with distilled water. Before using, the leaves were cut in discs (2 $\mathrm{cm}$ in diameter) and placed upside down in Petri dishes $(15 \mathrm{~cm}$ in diameter and $5 \mathrm{~cm}$ in high) which were lined on the edges with moistened cotton wool. In each Petri dish, 10 fertilized two-spotted spider mite adult females were placed on the leaf disks.

Mites were sprayed using a Potter spray tower $\left(15 \mathrm{lb} \mathrm{in} \mathrm{in}^{-2}\right)$ with $1.6 \mathrm{mg} \mathrm{cm}^{-2}$ of the solution. After spraying, the Petri dishes were transferred to an acclimatized chamber at $25.0 \pm 10^{\circ} \mathrm{C}$, relative humidity of $70.0 \pm 1.0 \%$ and photophase of $12 \mathrm{~h}$. With the aid of a stereomicroscope, the number of eggs laid and the number of dead mites were evaluated 24, 72 and 120 hours later. The mortality parameter considered mites that, with the touch of a brush, presented limited movement, i.e., did not move from its original position (STARK et al., 1997).

\section{Experimental design}

Tetranychus urticae generation used for evaluating the potential of the extract of $\boldsymbol{C}$. winterianus on mortality and number of eggs was distinct from the one used for the positive control 
(ICA). The experimental design was completely randomized with 10 replications, each corresponding to a disc with 10 mites, for each concentration of each product. The relationship between mortality, number of eggs and concentrations of the solutions obtained from the extract of citronella grass and ICA was evaluated by regression analysis using the software SIGMA PLOT ${ }^{\circledR}$ 11.0. Mortality was subjected to Probit analysis using the Polo-PC ${ }^{\circledR}$ software, which estimated the $\mathrm{LC}_{50}$.

\section{RESULTS AND DISCUSSION}

\section{Mortality of two-spotted spider mites}

Tetranychus urticae mortality was significantly affected by the extract of citronella grass and positive control at different concentrations. The data fitted the linear regression model $\left(\mathrm{Y}=\beta_{0}+\beta_{1} \mathrm{X}\right)$ with high statistical significance and coefficient of determination $\left(\mathrm{P}<0.001 ; \mathrm{R}^{2}>0.82\right)$ (Figure 1). The regression slope coefficients obtained for 24,72 and 120 hours after application of the extract of citronella were $\beta_{1(24 \text { Hours })}=13.2855 \pm 0.7818, \quad \beta_{1(72 \text { Hours })}=$ $12.8753 \pm 0.7984$ and $\beta_{1(120 \text { Hours })}=13.4594 \pm 0.5990$ and considering ICA $\beta_{1(24 \text { Hours })}=13.1345 \pm 0.5295, \beta_{1(72 \text { Hours })}$ $=13.6905 \pm 0.5395$ and $\beta_{1(120 \text { Hours })}=14.2628 \pm 0.5355$. These values were similar between products for each time of exposure indicating that the extract of citronella grass showed similar toxicity to ICA.

It was observed that the mortality of $\boldsymbol{T}$.

urticae increased with increasing concentrations of the extract of citronella grass and ICA. The exposure time also affected the survival of $T$. urticae. On average, the increase in mortality between 24 and 120 hours after application was $12 \%$ to the extract of citronella grass and $10 \%$ to ICA considering concentrations between 0 to $5 \%$. These results indicate that the majority of mite mortality occurred in 24 hours after application.

In the control was observed a cumulative mortality of $8.7 \%$ for the extract of citronella grass and $3.3 \%$ for ICA at 120 hours. These results are directly related to the natural mortality of the mite and also due to handling during the experiment. The extract of citronella grass and ICA at $1 \%$ caused, respectively, $31 \%$ and $24 \%$ of mortality 120 hours after application. Considering this time of exposure and the concentration of $5 \%$, the percentage of mortality caused by the extract of citronella grass and ICA were 78.9 and $77.8 \%$. As seen in figure 1 , if more concentrated solutions were tested the tendency would be to obtain higher mortality values.

Other studies have confirmed the toxicity of the ethanol extract of leaves of citronella grass ( $\boldsymbol{C}$. winterianus). At $5 \%$ this extract caused mortality of 93.7\% on tick Hyalomma anatolicum $\left(\mathrm{LC}_{50} 0.14 \%\right.$ ) and $\mathrm{LC}_{50}$ of $0.46 \%$ on Rhipicephalus (Boophilus) microplus (SINGH et al., 2014a; SINGH et al., 2014b).

It was observed that ICA at a concentration of 5\% caused $77.8 \%$ mortality of $\boldsymbol{T}$. urticae females

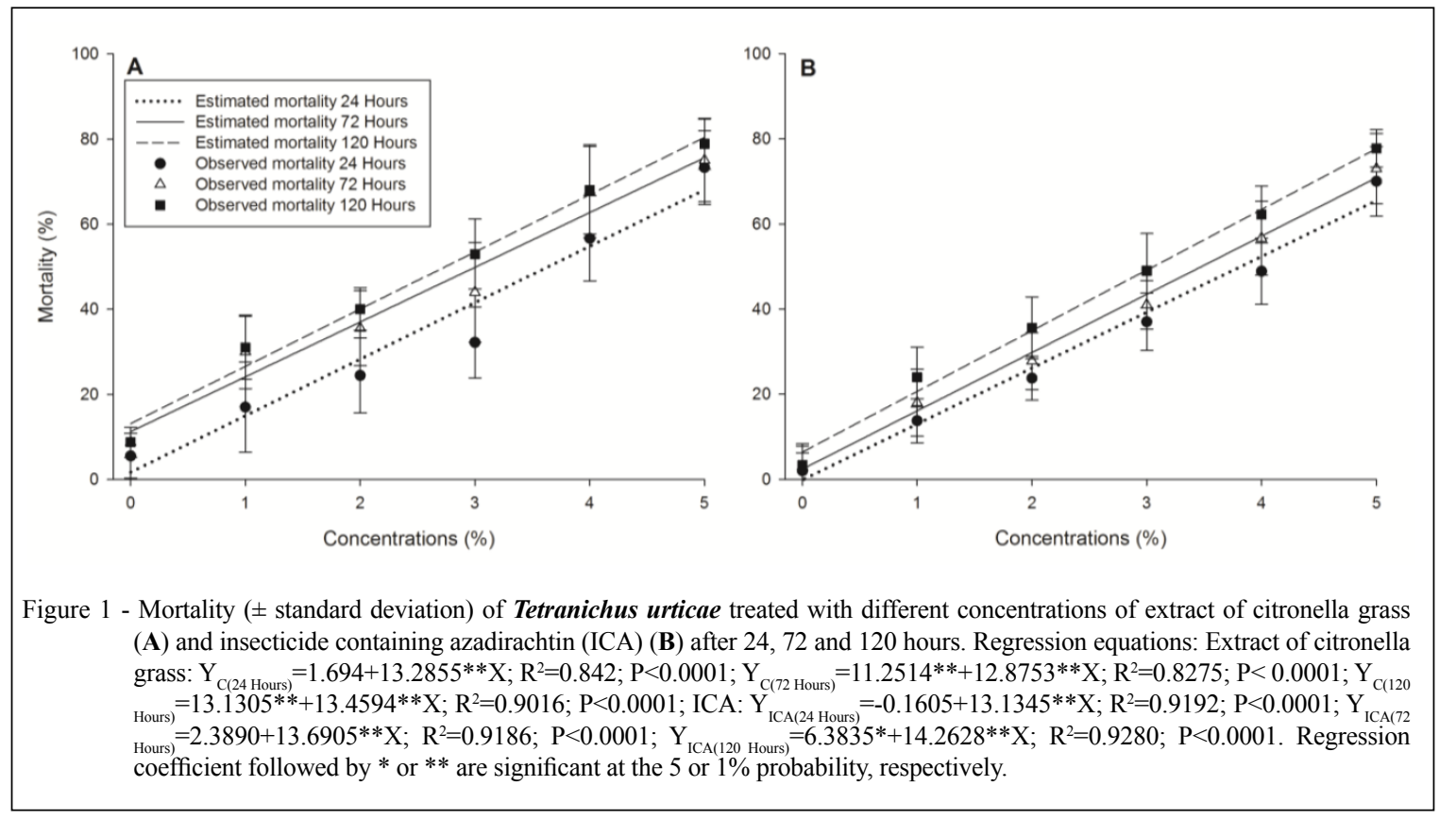

Ciência Rural, v.45, n.7, jul, 2015. 
(Figure 1). BERNARDI et al. (2012) found that ICA at a concentration of $0.3 \%$, after seven days of application, caused mortality in $79 \%$ of a population of adults and nymphs of $\boldsymbol{T}$. urticae. The difference between the results can be related to the populations of the pest once immature mites might be more sensitive to azadirachtin than adults. The effect of Neem-I-Go ${ }^{\circledR}$ at $5 \%$ was tested in leprosis mite in citrus (Brevipalpus phoenicis). It was observed that, after 120 hours, the mortality rate was $76 \%$ (JUSTINIANO et al., 2009).

Determination of $\mathrm{LC}_{50}$ values

$\mathrm{LC}_{50}$ value for citronella grass extract $(2.63 \%)$ was lower than the value for ICA $(2.83 \%)$. However, there was no significantly difference between them due to overlapping confidence intervals (Table 1). Higher $\mathrm{LC}_{50}$ values indicate less toxicity compared to the target organism, and consequently a greater amount of product is required to kill $50 \%$ of individuals in the population tested.

Initialy, these results endorse the possibility of using the extract of citronella grass in pest management programs of the two-spotted spider mite in strawberry plants. However, before using this extract under field conditions, it's important to consider that growing, harvesting and processing of citronella grass as well the storage and the preparation of its extract are factors that may affect the amount and the stability of the ingredient(s) active(s) (IA(s)). SARMA (2002) reported that the rain, temperature, light and humidity influence both in the yield of the extraction procedure as in the concentration of the extracted secondary metabolites in $\boldsymbol{C}$. winterianus. Although there haven't been found studies relating the stability of the IA(s) in the extracts of citronella grass, it is known that under field conditions, these substances are exposed to thermal and photodegradation. FERREIRA et al. (2013) reported that extracts of the Azadirachta indica (Neem), under

Table 1 - Estimation of the $\mathrm{LC}_{50}$ for ethanol extract of citronella grass (Cymbopogon winterianus) and insecticide containing azadirachtin (ICA) on Tetranychus urticae, after 120 hours.

\begin{tabular}{llccr}
\hline Treatments & $\mathrm{LC}_{50}(\mathrm{CI}$ a $95 \%)(\%)$ & $\mathrm{N}$ & $\chi 2$ & Slope $( \pm \mathrm{SE})$ \\
\hline $\begin{array}{l}\text { Citronella } \\
\text { grass }\end{array}$ & $2.63(1.41-3.83)$ & 480 & 4.64 n.s. & $2.03 \pm 0.32$ \\
ICA & $2.83(1.90-4.02)$ & 470 & 4.74 n.s. $2.12 \pm 0.29$
\end{tabular}

CI: Confidence interval for the $\mathrm{LC}_{50}$ at $95 \%$ probability; $\mathrm{N}$ : $\mathrm{n}^{\circ}$ of insects used in the bioassay; $\chi^{2}$ : Chi-square; SE: standard error; n.s.: non-significant. field conditions, can remain active for only three days. So, in these cases, the photoprotection of the IA(s) in the extracts is required.

Number of eggs of two-spotted spider mites The number of eggs laid by $\boldsymbol{T}$. urticae was affected by both products (extract of citronella grass and ICA) in the different concentrations tested (Figure 2). The parameter number of eggs showed a nonlinear tendency and the data fitted the exponential regression model $\left(\mathrm{Y}=\beta_{0} \operatorname{EXP}\left(-\beta_{1} \mathrm{X}\right)\right)$ with high statistical significance and coefficient of determination $\left(\mathrm{P}<0.001 ; \mathrm{R}^{2}>0.84\right)$.

At 24, 72 and 120 hours after application of both products, it was observed a difference in the number of eggs of $\boldsymbol{T}$. urticae when using extract of citronella grass and ICA at $0 \%$ of concentration (control). This can be explained due to the mite generation used for evaluating the potential of the extract of $\boldsymbol{C}$. winterianus on number of eggs was distinct from the one used for the positive control (ICA). Considering the different time intervals after the application of both products, it is possible to verify a pattern of reducing the number of eggs with increasing concentration of them (Figure 2). In general, the regression slope coefficients obtained in different times suggest that citronella grass $\left(\beta_{1(24}\right.$ Hours) $=0.3065 \pm 0.0196, \beta_{1(72 \text { Hours })}=0.3945 \pm 0.0163$ and $\left.\beta_{1(120 \text { Hours })}=0.3807 \pm 0.0184\right)$ and ICA $\left(\beta_{1(24 \text { Hours })}\right.$ $=0.2783 \pm 0.0121, \beta_{1(72 \text { Hours })}=0.2698 \pm 0.0129$ and $\left.\beta_{1(120 \text { Hours })}=0.2655 \pm 0.0123\right)$ present similar action on population reduction (eggs deposition) of $\boldsymbol{T}$. urticae.

The greatest reduction in the number of eggs was observed for the different concentrations of the extract of citronella grass after 120 hours. After 24 hours the number of eggs observed when testing concentrations of $0 \%$ (control), $1 \%$ and $5 \%$ were 37, 21 and 9, respectively. On the other hand, at concentrations of $0 \%, 1 \%$ and $5 \%$ were observed 115,65 and 16 eggs, respectively, after 120 hours. Then, after 24 and 120 hours and considering the concentration of $5 \%$, the egg inhibition observed was 76 and $86 \%$, respectively (Figure 2). This suggests that this extract had a deterrent effect on females of $\boldsymbol{T}$. urticae in relation to number of eggs. The reduction in the number of eggs may also be due to the fact that the mites had died (Figure 1), making impossible the deposition of eggs. Thus, the extract of citronella grass contributed to decrease the population/offspring of $\boldsymbol{T}$. urticae. According to SINGH et al. (2014b), percent inhibition of oviposition of $58 \%$ was observed by the ethanolic extract of $\boldsymbol{C}$. winterianus against $\boldsymbol{R}$. (B.) microplus. 

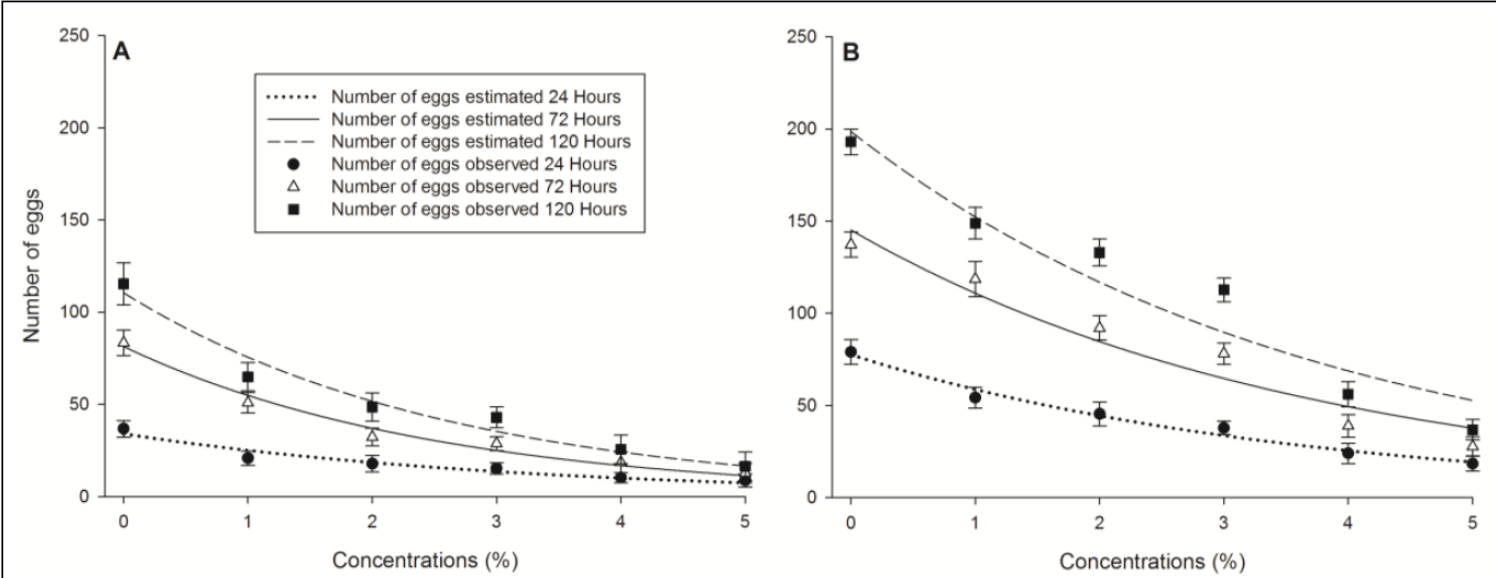

Figure 2 - Number of eggs ( \pm standard deviation) by Tetranichus urticae treated with different concentrations of extract of citronella grass (A) and insecticide containing azadirachtin (ICA) (B) after 24, 72 and 120 hours. Regression equations: Extract of citronella grass: $\mathrm{Y}_{\mathrm{C}(24 \text { Hours })}=33.9379 * * \mathrm{EXP}(-0.3065 * * \mathrm{X}) ; \mathrm{R}^{2}=0.8481 ; \mathrm{P}<0.0001 ; \mathrm{Y}_{\mathrm{C}(72 \text { Hours }}=81.3335 * * \mathrm{EXP}(-$ $\left.0.3945^{* * X}\right) ; \mathrm{R}^{2}=0.9427 ; \mathrm{P}<0.0001 ; \mathrm{Y}_{\mathrm{C}(120 \text { Hours })}=110.4065^{* *} \operatorname{EXP}\left(-0.3807^{* * \mathrm{X})} ; \mathrm{R}^{2}=0.9146 ; \mathrm{P}<0.0001 ; \mathrm{ICA}^{*}: \mathrm{Y}_{\mathrm{ICA}(24}\right.$ $=77.4785 * * \operatorname{EXP}(-0.2783 * * \mathrm{X}) ; \mathrm{R}^{2}=0.9224 ; \mathrm{P}<0.0001 ; \mathrm{Y}_{\mathrm{ICA}(72 \text { Hours })}=145.2156 * * \mathrm{EXP}(-0.2698 * \mathrm{X}) ; \mathrm{R}^{2}=0.9192 ;$ $\mathrm{P}<0.0001 ; \mathrm{Y}_{\text {ICA(120 Hours })}=198.6560 * * \operatorname{EXP}\left(-0.2655^{*} * \mathrm{X}\right) ; \mathrm{R}^{2}=0.9214 ; \mathrm{P}<0.0001$. Regression coefficient followed by $*$ or ** are significant at the 5 or $1 \%$ probability, respectively.

A progressive reduction in number of eggs was also observed with increasing concentration of ICA (Figure 2). With respect to 24 hours after the application of the positive control and for concentrations of $0 \%$ (control), $1 \%$ and $5 \%$ were observed 79, 54 and 18 eggs, respectively. After the time of exposure of 120 hours, at $0 \%, 1 \%$ and $5 \%$ were observed 193, 149 and 37 eggs, respectively. Regarding these values, reductions in the average number of eggs after application of ICA at 5\% after 24 and 120 hours were 77 and $81 \%$, respectively.

Azadirachtin alters the ecdysis, due to its similarity to the hormone that regulates this process in the insect, mainly resulting in the death of the young forms, reducing food intake and slowing development. It also reduce fecundity and cause partial or total sterility of eggs wich interfere with the functioning of the endocrine glands that control metamorphosis in insects, preventing development in the larval phase and inhibit chitin synthesis required for development of the insects (GAJMER et al., 2002; MARÇON, 2003).

\section{CONCLUSION}

The ethanol extract of citronella grass promoted high mortality and showed a significantly reduced on number of eggs on $\boldsymbol{T}$. urticae, in laboratory conditions. These results suggests its potential use in controlling this mite population. However, further research must be conducted, under field conditions, to evaluate the use of this extract on control of other T. urticae populations that infect strawberry crop and other economic relevance crops. For the use of this extract in pest management programs, the efficiency and mode of action of compounds present in the tested formulations must still be elucidated. Toxicological tests must also be performed to evaluate the possible effects on human health, non-target organisms and in the environment.

\section{ACKNOWLEDGEMENTS}

The authors acknowledge the support of the Fundação de Amparo à Pesquisa do Estado do Espírito Santo (FAPES), Conselho Nacional de Desenvolvimento Científico e Tecnológico $(\mathrm{CNPq})$ and Financiadora de Estudos e Projetos (FINEP).

\section{REFERENCES}

ADAKOLE, J.A.; ADEYEMI, A.F.F. Larvicidal effects of Cymbopogon citratus (lemon grass) extract against Culex quinquefasciatus qularvae (Diptera, Culicidae). Available from: $<$ http://www.thefreelibrary.com/Larvicidal effects of Cymbopogon citratus (lemon grass) extract...-a0323258128>.Accessed: June 29, 2014. Online.

ATTIA, S. et al. A review of the major biological approaches to control the worldwide pest Tetranychus urticae (Acari: Tetranychidae) with special reference to natural pesticides. Journal of Pest Science, v.86, n.3, p.361-386, 2013.

BERNARDI, D. et al. Effects of azadirachtin on Tetranychus urticae (Acari: Tetranychidae) and its compatibility with predatory mites (Acari: Phytoseiidae) on strawberry. Pest Management Science, v.69, n.1, p.75-80, 2012. 
BIZZO, H.R. et al. Óleos essenciais no Brasil: aspectos gerais, desenvolvimento e perspectivas. Química Nova, v.32, n.3, p.588594, 2009.

CHIAVEGATO, L.G.; MISCHAN, M.M. Efeito do Tetranychus (T.) urticae (Koch, 1836) Boudreaux \& Dosse, 1963 (Acari, Tetranychidae) na produção do morangueiro (Fragaria sp.) cv. 'Campinas'. Científica, v.9, n.2, p.257-266, 1981.

FADINI, M.A.M. et al. Controle de ácaros em sistema de produção integrada de morango. Ciência Rural, v.34, n.4, p.1271-1277, 2004.

FERREIRA, E.N. et al. Análise da fotoestabilidade de extratos de nim formulados com protetores orgânicos comerciais. São Carlos, SP, 2013. In: JORNADA CIENTÍFICA E TECNOLÓGICA DA UFSCAR, 10., 2013, São Carlos, SP. Anais... São Carlos: UFSCAR, 2013. V.9.

FLECHTMANN, C.H.W. Ácaros de importância agrícola. São Paulo: Livraria Nobel, 1979. 189p.

GAJMER, T. et al. Effect of methanolic extracts of neem (Azadirachta indica A. Juss) and bakain (Melia azedarach L.) seeds on oviposition and egg hatching of Earias vittella (Fab.) (Lep., Noctuidae). Journal of Applied Entomology, v.126, n.5, p.38-243, 2002.

GALLO, D. et al. Entomologia agrícola. Piracicaba: Fealq, 2002. 920p.

HAN, J. et al. Fumigant toxicity of lemon eucalyptus oil constituents to acaricide-susceptible and acaricide-resistant Tetranychus urticae Pest Management Science, v.67, n.2, p.609-740, 2011.

JAYASINHA, P. Citronella (Cymbopogon nardus). Colombo: Information Services Centre, Industrial Technology Institute, 1999. $45 \mathrm{p}$

JUSTINIANO, W. et al. Eficiência do óleo de nem no controle do ácaro da leprose dos citros Brevipalpus phoenicis
(Geijskes, 1939). Pesquisa Agropecuária Tropical, v.39, n.1, p.38-42, 2009.

MARÇON, P.G. Modo de ação de inseticidas e acaricidas. São Paulo: DuPont do Brasil S.A., 2003. 7p. (Informativo Dupont, 21).

SARMA, T.C. Variation in oil and its major constituents due to season and stage of the crop in Java citronella Cymbopogon winterianus Jowitt. Journal of Spices and Aromatic Crops, v.11, n.2, p.97-100, 2002

SATO, M.E. et al. Selections for fenpyroximate resistance and susceptibility, and inheritance, crossresistance and stability of fenpyroximate resistance in Tetranychus urticae Koch (Acari: Tetranychidae). Applied Entomology and Zoology, v.39, n.2, p.293-302, 2004.

SCHWIRKOWSKI, P. Projeto de divulgação da flora nativa e exótica da cidade de São Bento do Sul (FloraSBS). Available from: $<$ https://sites.google.com/site/florasbs/poaceae/capim-limao $>$. Accessed: Dec. 09, 2009. Online.

SINGH, N.K. et al. Laboratory assessment of acaricidal activity of Cymbopogon winterianus, Vitex negundo and Withania somnifera extracts against deltamethrin resistant Hyalomma anatolicum. Experimental and Applied Acarology, v.63, n.3, p.423-430, 2014a

SINGH, N.K. et al. Acaricidal activity of Cymbopogon winterianus, Vitex negundo and Withania somnifera against synthetic pyrethroid resistant Rhipicephalus (Boophilus) microplus. Parasitology Research, v.113, n.1, p.341-350, 2014 b.

STARK, J.D. et al. Reproductive potential: its influence on the susceptibility of a species to pesticides. Ecotoxicology and Environmental Safety, v.37, n.3, p.273-279, 1997.

THEIN, W.M. et al. Insecticidal activity of crude plant extracts against Sitophilus spp. (Coleoptera: Curculionidae) and Callosobruchus chinensis (L.) (Coleoptera: Bruchidae). Philippine Agricultural Scientist, v.96, n.2, p.154-162, 2013. 